\title{
Penerapan Model Pembelajaran Kooperatif Tipe Teams Game Tournament (TGT) untuk Meningkatkan Minat Belajar PKn
}

\section{Ni Nyoman Sukasih*}

Sekolah Dasar No 1 Darmasaba, Bali

\author{
A R T I C L E I N F O \\ Article history: \\ Received 18 May 2018 \\ Received in revised form \\ 9 June 2018 \\ Accepted 15 July 2018 \\ Available online 18 August \\ 2018 \\ Kata Kunci: \\ TGT, Minat bejalar PKn \\ Keywords: \\ TGT, learning interest, PKn.
}

\begin{abstract}
A B S T R A K
Penelitian ini bertujuan untuk mengetahui peningkatan minat belajar PKn siswa Kelas V Semester II tahun pelajaran 2015/2016 di SD No 1 Darmasaba setelah Penerapan Model Pembelajaran Kooperatif Tipe Teams Game Tournament (TGT). Jenis penelitian ini adalah penelitian tindakan kelas (PTK) dengan subjek penelitian siswa kelas $\mathrm{V}$ semester II tahun pelajaran 2015/2016 sebanyak 26 orang. Data minat belajar PKn dikumpulkan dengan lembar observasi. Data yang diperoleh dianalisis menggunakan analisis statistik deskriptif. Berdasarkan hasil temuan penelitian dan pembahasan, dapat disimpulkan bahwa penerapan model pembelajaran Kooperatif tipe TGT dapat meningkatkan minat belajar PKn pada siswa kelas $\mathrm{V}$ tahun pelajaran 2015/2016 di SD No 1 Darmasaba. Hasil ini terbukti dari peningkatan rata-rata minat siklus I sebesar 16 menjadi 20 pada siklus II. Ketuntasan klasikal siswa pun mengalami peningkatan dari $77 \%$ pada siklus I menjadi $100 \%$ pada siklus II.
\end{abstract}

\section{A B S T R A C T}

This research aimed at implementing cooperative learning type Teams Game Tournament (TGT) to improve students' learning interest in civic education. The subjects of this classroom action research were 26 students in Grade V, semester II, academic year 2015/2016 in SD No.1 Darmasaba. Students' interests were collected using observation sheet and analyzed descriptively. Result showed that the implementation of cooperative learning type TGT could improve students' interest in civic education. Students' interests were increase from 16 after Cycle I to 20 after Cycle II. Students' classical completeness was also increase from $77 \%$ after Cycle I to $100 \%$ after Cycle II. 


\section{Pendahuluan}

Perkembangan teknologi informasi yang terjadi sangat cepat telah memberi pengaruh besar terhadap dunia pendidikan. Perkembangan teknologi mengakibatkan berkembangnya ilmu pengetahuan, baik ke arah yang positif maupun ke arah yang negatif. Perkembangan teknologi tidak hanya terjadi di negara maju tetapi juga di negara-negara berkembang. Indonesia sebagai salah satu negara yang sedang berkembang tidak dapat menghindar dari perkembangan teknologi yang memberi pengaruh terhadap dunia pendidikan. Pendidikan bagi negara yang sedang berkembang merupakan suatu media yang sangat berperan dalam menciptakan Sumber Daya Manusia (SDM) yang berkualitas. Hal ini sejalan dengan pernyataan yang dikemukakan oleh Nasution (2009) yang menyebutkan bahwa negara-negara yang sedang berkembang memandang pendidikan sebagai alat yang paling ampuh untuk menyiapakan tenaga yang terampil dan ahli dalam segala sektor pembangunan. Kesuksesan dalam sektor pembangunan tidak hanya dipengaruhi kemampuan dalam bidang ekonomi, tetapi juga dipengaruhi oleh kualitas SDM yang menjalankan proses pembangunan tersebut. Melalui pendidikan itulah diharapkan dapat tercapai pembangunan yang utuh, sehingga terjadi peningkatan taraf kehidupan manusia ke arah yang lebih sempurna.

Untuk mengatasi kualitas SDM tersebut, secara intensif pemerintah terus melaksanakan upaya peningkatan mutu pendidikan pada semua jenis dan jenjang pendidikan. Banyak cara yang telah dilakukan oleh pemerintah dalam meningkatkan mutu pendidikan, salah satunya tercermin dari anggaran pendidikan yang disediakan dalam APBN dan APBD. Menurut Toyamah dan Syaikhu Usman (2004), besarnya anggaran dana pendidikan adalah sesuai dengan yang ada dalam amandemen Pasal 31 UUD 1945 dan dipertegas dalam Pasal 49 No. 20 Tahun 2003 tentang Sisdiknas, bahwa dana pendidikan selain gaji pendidik dan biaya pendidikan kedinasan dialokasikan minimal 20\% dari APBN dan APBD. Selain dengan penyediaan dana pendidikan yang begitu besar, berbagai upaya lain juga telah ditempuh dalam meningkatkan kualitas pendidikan, antara lain pembaharuan dalam kurikulum, pengembangan model pembelajaran, diadakannya penataran bagi guru-guru, penyebaran guru dan media pembelajaran, serta perbaikan sarana dan prasarana pendidikan.

Berbagai upaya yang dilakukan pemerintah tidak akan berarti apa-apa jika guru sebagai pondasi dasar pendidikan tidak berperan aktif didalamnya. Sudjana (1987) menyebutkan bahwa, Guru dalam pendidikan menempati kedudukan sentral, sebab peranannya sangat menentukan. Ia harus mampu menterjemahkan dan menjabarkan nilai-nilai yang terdapat dalam kurikulum, kemudian mentransformasikan nilai-nilai tersebut kepada siswa melalui proses pengajaran di sekolah. Guru tidak membuat/menyusun kurikulum, tapi ia menggunakan kurikulum, menjabarkannya, serta melaksanakan melalui proses pembelajaran.

Kecermatan guru dalam menyusun kegiatan pembelajaran sangat menentukan kualitas proses dan hasil pembelajaran. Kenyataan yang ada dilapangan saat ini menunjukan bahwa kebanyakan guru masih menerapkan model pembelajaran dengan paradigma pembelajaran lama, yaitu guru sebagai pusat pembelajaran (teacher centered). Hal ini membuat siswa dalam proses pembelajaran menjadi kurang aktif. Padahal, sebenarnya proses pembelajaran bukan semata-mata memberikan segala informasi dan keterampilan kepada peserta didik, melainkan lebih menekankan pada proses yang melibatkan siswa secara aktif dalam mengembangkan potensi yang dimiliki siswa.

Untuk melibatkan siswa secara aktif dalam memahami konsep-konsep PKn tidaklah mudah. Guru dituntut memiliki kemampuan dan kreativitas tinggi dalam merancang kegiatan pembelajaran PKn. Selain itu, guru juga dituntut untuk mampu menggunakan media atau alat peraga pembelajaran sesuai dengan materi PKn yang akan dikaji. Siswa dapat memahami suatu konsep PKn dengan baik dan mudah apabila dalam proses pembelajaran konsep tersebut dilakukan dengan kegiatan yang bermakna dan langsung melibatkan siswa secara aktif. Untuk merealisasikan hal ini maka dibutuhkan suatu model pembelajaran yang secara tidak langsung dapat melibatkan siswa dalam proses pembelajaran, salah satunya adalah dengan menerapkan model pembelajaran kooperatif.

Menurut Riyanto (2010), pembelajaran kooperatif adalah model pembelajaran yang dirancang untuk membelajarkan kecakapan akademik (academic skill), sekaligus keterampilan sosial (social skill) termasuk interpersonal skill. Melalui pembelajaran kooperatif akan dapat terlaksana kegiatan belajar yang aktif dan keterampilan/kemampuan yang dimiliki siswa dapat berkembang secara bersamaan, baik kemampuan akademis maupun keterampilan dalam bersosialisasi. Salah satu pembelajaran kooperatif adalah model pembelajaran Teams Games Tournament (TGT). TGT memungkinkan siswa dapat belajar lebih relaks di samping menumbuhkan tanggung jawab, kerja sama, persaingan sehat, dan keterlibatan belajar (Kariyana, 2014). Purwandari (2017) mengatakan bahwa dengan menerapkan model pembelajaran TGT di kelas diharapkan dapat menghilangkan anggapan siswa tentang pelajaran yang membosankan. Sudimahayasa (2015) mngatakan bahwa TGT menambahkan dimensi kegembiraan yang 
diperoleh dari penggunaan permainan. Salah satu tipe model cooperative adalah teams games tournament (TGT) yang sangat menekankan pada pentingnya interaksi dalam tim (Marianti :2017).

Selain dengan menggunakan model pembelajaran kooperatif, hal lain yang dapat dilakukan agar dalam kegiatan pembelajaran konsep lebih bermakna adalah dengan menggunakan alat peraga. Alat peraga merupakan semua benda yang dijadikan perantaran dalam proses pembelajaran. Melalui alat peraga siswa dapat secara langsung memanipulasi objek yang terkait dengan konsep yang diajarkan, sehingga konsep-konsep tersebut akan melekat dengan baik diingatan siswa.

Sampai saat ini masih banyak ditemukan kesulitan-kesulitan yang dialami siswa dalam mempelajari konsep PKn. Kesulitan siswa dalam memahami suatu konsep PKn disebabkan karena guru dalam mengajarkan suatu konsep PKn kepada siswa cenderung berpusat kepada guru. Guru kurang memperhatikan kemampuan yang dimiliki siswa, umumnya siswa lebih banyak memperoleh pengalaman tak langsung dalam proses pembelajaran. Siswa lebih banyak memperoleh informasi pada taraf percaya, baik percaya pada informasi yang diberikan guru maupun dari buku. Hal ini terlihat dari nilai ulangan harian PKn siswa kelas V di SD No 1 Darmasaba masih berada di bawah KKM (Kriteria Ketuntasan Minimal). Di mana KKM yang ditetapkan oleh sekolah sebagai standar tercapainya tujuan pembelajaran adalah 70. Berdasarkan latar belakang tersebut, penelitian ini bertujuan untuk meningkatkan minat belajar PKn siswa Kelas V Semester II tahun pelajaran 2015/2016 di SD No 1 Darmasaba melalui penerapan Model Pembelajaran Kooperatif Tipe Teams Game Tournament (TGT).

\section{Metode}

Penelitian ini dilaksanakan di SD No 1 Darmasaba semester II tahun pelajaran 2015/2016. Penelitian ini dilaksanakan dari bulan Februari sampai Mei 2016. Dalam penelitian ini yang menjadi subjek penelitian adalah siswa kelas V di SD No 1 Darmasaba semester II tahun pelajaran 2015/2016 sebanyak 26 orang. Sedangkan objek dari penelitian ini adalah minat belajar dengan penerapan model pembelajaran kooperatif tipe TGT. Jenis penelitian ini adalah penelitian tindakan kelas (PTK). Menurut Agung (2010:3), penelitian tindakan kelas merupakan penelitian yang bersifat aplikasi (terapan), terbatas, segera, dan hasilnya untuk memperbaiki dan menyempurnakan proses atau program (program pembelajaran) yang sedang berlangsung. Penelitian tindak kelas ditandai dengan adanya perbaikan terus menerus sehingga tercapai sasaran dari penelitian tersebut". Berdasarkan pengertian tersebut, dapat disimpulkan bahwa penelitian tindakan kelas merupakan suatu penelitian yang bertujuan untuk memperbaiki praktik pembelajaran guna meningkatkan mutu pembelajaran.

Penelitian tindakan kelas (PTK) ini ada empat tahapan pada satu siklus penelitian. Keempat tahapan tersebut terdiri dari: planing, action, observation/evaluation, dan reflection. Pelaksanaan penelitian ini dilakukan dalam dua siklus, dan kedua siklus tersebut dapat digambarkan dalam model seperti gambar sebagai berikut.

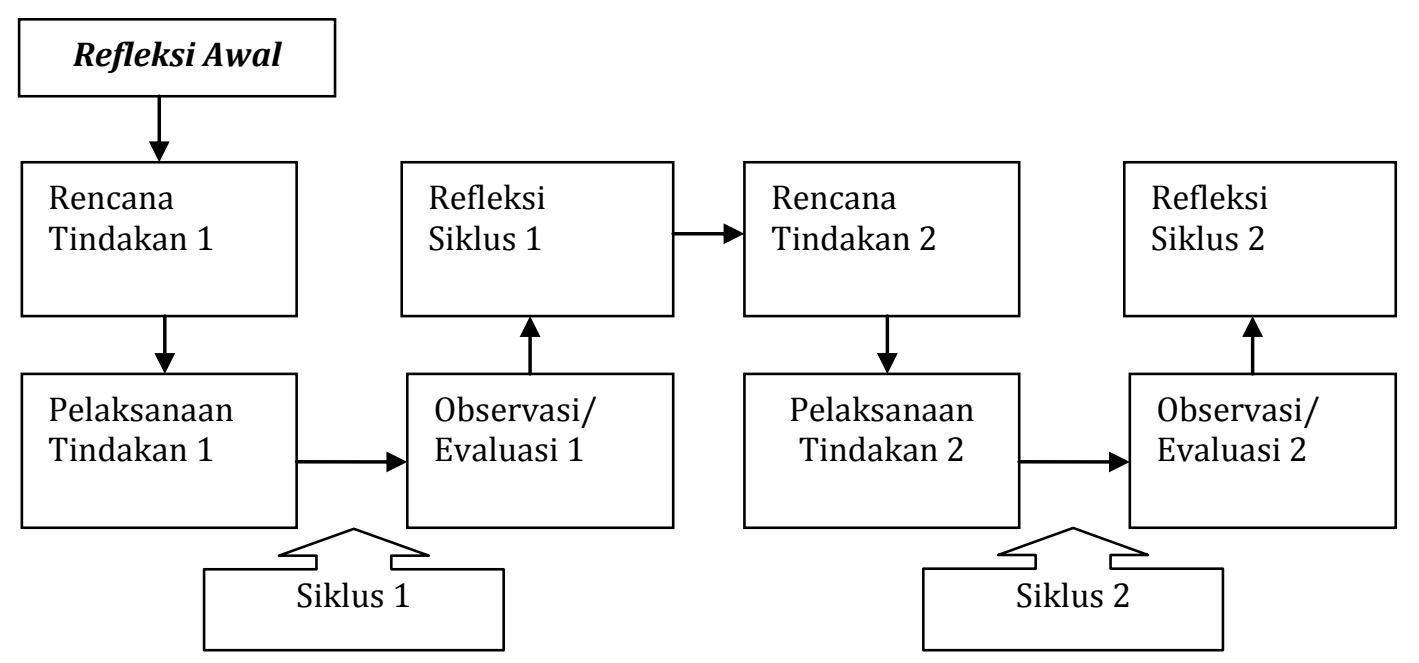

Gambar 1. Model Penelitian Tindakan Kelas Dua Siklus (Agung, 2010)

Dalam penelitian ini digunakan metode pengumpulan data yaitu metode observasi. Metode observasi merupakan salah satu dari berbagai metode dalam pengumpulan data. Menurut Agung 
(2010:55), metode observasi adalah suatu cara memperoleh data dengan jalan mengadakan pengamatan dan pencatatan secara sistematis tentang suatu objek tertentu.

Setelah data dalam penelitian ini terkumpul selanjutnya dilakukan analisis data. Ada dua jenis metode analisis statistik yaitu metode analisis statistik deskriptif. Dalam penerapan metode analisis statistik deskriptif ini, data yang diperoleh dari hasil penelitian dianalisis dan disajikan ke dalam: a) menghitung angka rata-rata (Mean), b) menghitung median, c) menghitung modus. Mean, median modus dihitung dengan bantuan Microsoft excel. Indikator keberhasilan pelaksanaan ini, berpedoman pada kriteria berikut. Tingkat keberhasilan dalam penelitian ini adalah apabila rata-rata minat belajar siswa minimal pada kategori Tinggi, dan ketuntasan klasikal sebesar 90\%.

\section{Hasil dan Pembahasan}

Pada siklus I Rata-rata minat belajar siswa= 16 yang dikonvesikan ke dalam PAP skala lima, berada pada tingkat minat $16,5>X>13,5$ yang berarti bahwa tingkat minat belajar siswa siklus I tergolong sedang. Ketuntasan klasikalnya $=77 \%$, karena belum semua siswa memiliki minat yang tinggi, masih ada 6 orang yang mendapatkan rata-rata minat rendah.

Kendala yang dihadapi pada siklus I adalah guru belum mampu menciptakan suasana belajar aktif dan menyenangkan, belum semua siswa memahami materi pembelajaran yang disampaikan, kerjasama antar sesama siswa masih kurang, dan masih banyak siswa yang lain-lain saat guru menjelaskan.

Kendala tersebut diatasi dengan memaksimalkan pelaksanaan model Pembelajaran Kooperatif TGT sehingga pembelajaran lebih menyenangkan, mengajak siswa untuk berkonsentrasi pada pelajarannya, menumbuhkan kerjasama dan gotong royong pada siswa dengan mengajak melakukan pembelajaran yang bermakna.

Berdasarkan pemaparan di atas, kategori minat belajar siswa berada pada kategori sedang dan ketuntasan siswa tidak mencapai $90 \%$ sehingga belum mencapai kategori dan kategori yang ditetapkan oleh peneliti, yakni kategori minat belajar siswa berada pada kategori minimal tinggi dan dan ketutasan klasikal 90\%. Sehingga dapat disimpulkan bahwa siklus I belum berhasil dan harus diadakan siklus II dengan memperhatikan kendala-kendala yang dihadapi siklus I.

Pada siklus II rata-rata minat belajar siswa $=20$ yang dikonvesikan ke dalam PAP skala lima, berada pada tingkat minat $X>19,5$ yang berarti bahwa tingkat minat belajar siswa siklus I tergolong sangat tinggi. Ketuntasan klasikalnya $=100 \%$.

Hal ini menunjukkan bahwa kendala-kendala yang dihadapi pada siklus I sudah dapat diatasi pada siklus II. Maka dari itu kriteria ketuntasan minimal baik dan ketuntasan klasikal $90 \%$ sudah terpenuhi sehingga penelitian pada siklus II dinyatakan berhasil dan siklus dihentikan.

Untuk lebih jelasnya, peningkatan dari siklus I ke siklus II dapat digambarkan dalam grafik. Ketuntasan klasikal minat belajar siswa siklus I dan siklus II dapat digambarkan pada gambar berikut.

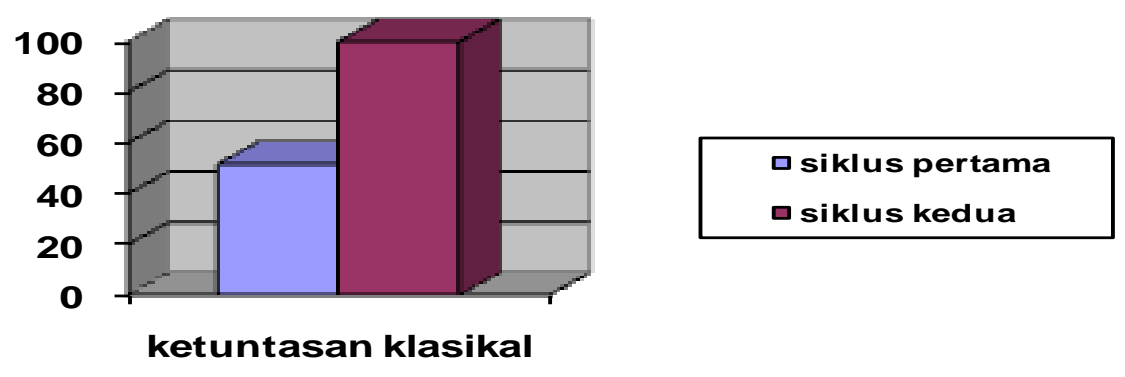

Gambar 2. Ketuntasasn Klasikal Siklus I dan Siklus II

Berdasarkan Gambar 2. terlihat peningkatan yang signifikan antara hasil minat belajar siswa pada dari siklus I ke siklus II sehingga dapat disimpulkan bahwa penerapan model pembelajaran Kooperatif tipe TGT dapat meningkatkan minat belajar pada siswa kelas V tahun pelajaran 2015/2016 di SD No 1 Darmasaba.

Hasil penelitian ini sejalan dengan hasil penelitian Astrawan (2011) yang menunjukan bahwa penerapan model pembelajaran kooperatif tipe TGT dalam pembelajaran IPA kelas V SD No. 5 Banyuning tahun pelajaran 2010/2011 dapat meningkatkan minat dan hasil belajar siswa. Peningkatan terjadi 
karena siswa merasa terminat untuk belajar dengan adanya diskusi kelompok belajar, games tournament dan penghargaan kelompok.

\section{Simpulan dan Saran}

Berdasarkan hasil penelitian yang telah dibahas pada bab IV, maka dapat dapat disimpulkan bahwa penerapan model pembelajaran Kooperatif tipe TGT dapat meningkatkan minat belajar PKn pada siswa kelas V tahun pelajaran 2015/2016 di SD No 1 Darmasaba. Hasil ini terbukti dari peningkatan rata-rata minat siklus I sebesar 16 menjadi 20 pada siklus II. Ketuntasan klasikal siswa pun mengalami peningkatan dari $77 \%$ pada siklus I menjadi $100 \%$ pada siklus II.

Saran yang dapat disampaikan berdasarkan penelitian yang telah dilakukan adalah sebagai berikut. 1) Disarankan kepada siswa-siswa kelas V tahun pelajaran 2015/2016 di SD No 1 Darmasaba agar lebih mengembangkan pengetahuaan dan menumbuhkan kreatifitas dalam belajar sehingga hasil yang dicapai optimal, 2) Disarankan kepada guru-guru khususnya di SD No 1 Darmasaba agar lebih kreatif dalam mengembangkan pembelajaran sehingga siswa menemukan suatu hal baru yang menyebabkan ingatannya pada pelajaran melekat lebih lama. 3) Disarankan kepada sekolah-sekolah yang mengalami permasalahan rendahnya minat belajar, disarankan untuk menerapkan model pembelajaran Kooperatif tipe TGT.

\section{Daftar Rujukan}

Agung, A. A. G. 2010. Metodologi Penelitian Pendidikan (Suatu Pengantar). Singaraja: Fakultas Ilmu Pendidikan Undiksha Singaraja.

Astrawan, I Wayan Juni. 2011. Penerapan Model Pembelajaran Kooperatif Tipe Team (TGT) untuk Meniingkatkan Minat dan Hasil Belajar IPA Siswa Kelas V SD No.5 Banyuning Kecamatan Buleleng Kabupaten Buleleng Tahun Pelajaran 2010/2011. Skripsi (tidak dipublikasikan). Jurusan Pendidikan Guru sekolah Dasar, Fakultas Ilmu Pendidikan, Universitas Pendidikan Ganesha.

Astuti, Ni Putu Eka Yuni. 2011. "Studi Komparasi Penggunaan Model Pembelajaran Teams Games Tournament (TGT) dengan Pembelajaran Langsung (Direct Instruction/DI) terhadap Hasil Belajar Siswa pada Pelajaran PKn Kelas VIII di SMP 6 Singaraja Tahun 2011". E- Jurnal Undiksha Vol 1 No 1 $2011(25)$.

Dewiyanti , Ni Kd. \& I Kt Adnyana P., I W. Wiarta. 2018. "Pengaruh Model Pembelajaran Team Games Tournament (TGT) Berbantuan Media Permainan Ular Tangga terhadap Hasil Belajar Matematika “. JIPP Volume 2 Nomor 1 April 2018 (29-37).

Fatmawati. As., I Nym. Jampel, I Wyn. Widiana. 2013. "Pengaruh Model Pembelajaran TGT (Teams Games Tournament) Terhadap Hasil Belajar IPA Pada Siswa Kelas V SD”. E-journal Universitas Pendidikan Ganesha. Di akses melalui ejournal.undiksha.ac.id/index.php/JJPGSD/article\%20/viewFile/1262/1125.

Kariyana, I Kadek.2014 "Implementasi Pembelajaran Kooperatif TGT untuk Meningkatkan Aktivitas dan Hasil Belajar Dribbling Sepakbola". Jurnal Penjakora Vol 2 No 12014 (1-11).

Marianti dan Ratnawati Susanto 2017. "Pengaruh Model Cooperative Learning Tipe Teams Games Tournament (TGT) terhadap Kecerdasan Interpersonal Pada Mata Pelajaran IPS". Jurnal Ilmiah Sekolah Dasar Vol.1 (4) pp. 260-269.

Muliantika, Pt. Frendita I Gd. Margunayasa, I Md. Citra Wibawa. 2017. "Pengaruh Model Pembelajaran Tipe Teams Games Tournament (TGT) terhadap Hasil Belajar IPA Siswa Kelas V SD". e-Journal PGSD Universitas Pendidikan Ganesha Mimbar PGSD Vol: 5 No: 2.

Nasution, S. 2009. Sosiologi Pendidikan. Edisi Kedua. Cetakan Keempat. Jakarta: Bumi Angkasa.

Purwandari, Amanda \& Dyah Tri Wahyuningtyas. 2017. "Eksperimen Model Pembelajaran Teams Games Tournament (TGT) Berbantuan Media Keranjang Biji-Bijian terhadap Hasil Belajar Materi Perkalian 
dan Pembagian Siswa Kelas II SDN Saptorenggo". Jurnal Ilmiah Sekolah Dasar. Vol.1 (3) pp. 163170.

Putri, Dewi Siswanti \& Mawardi.2017. " The Application Of Teams-Games-Tournament (TGT) To Increase Students' Activeness And Learning Outcomes “. Jurnal Pendidikan dan Pengajaran, 50 (2), July 2017, 60-68.

Priliyani, Eka. Mujihardi. 2014. "Penerapan Model TGT (Teams Games Tournament) Menggunakan Media Monopoli Bilangan Materi Penjumlahan dan Pengurangan untuk Meningkatkan Keaktifan Siswa Kelas II SDN Kalirejo II Kabupaten Pasuruan". Junal Malang: FKIP Universitas Kanjuruhan.

Qurrota, Dewi \& I Nyoman Suardana, I Made Suwenten, 2017. “Penerapan Model Pembelajaran Kooperatif Tipe TGT (Teams Games Tournament) untuk Meningkatkan Motivasi dan Hasil Belajar Peserta Didik". Jurnal Pendidikan Kimia Indonesia Volume 1, Nomor 2, 2017.

Riyanto, Yatim. 2010. Paradigma Baru Pembelajaran: Sebagai Refrensi Bagi Guru/Pendidik dalam Implementasi Pembelajaran yang Efektif dan Berkualitas. Edisi Pertama. Cetakan Kedua. Surabaya: Kencana Prenada Media Group.

Rohmah, Emay Aenu, Wahyudin. 2016. "Pengaruh Model Pembelajaran Kooperatif Tipe Teams Games Tournament (TGT) Berbantuan Media Game Online Terhadap Pemahaman Konsep Dan Penalaran Matematis Siswa". EduHumaniora: Jurnal Pendidikan Dasar, ISSN 2085-1243 Vo. 8. No.2 Hal 126143.

Saptayanti, Gusti Ayu Kade Emi, I Made Citra Wibawa, Ketut Pudjawan. 2016. "Pengaruh Model Pembelajaran Kooperatif Tipe TGT (Teams Games Tournament) Terhadap Hasil Belajar Matematika". e-Journal PGSD Universitas Pendidikan Ganesha Jurusan PGSD Vol: 4 No: 1.

Solihah, Ai. 2016. "Pengaruh Model Pembelajaran Teams Games Tournament (TGT) terhadap Hasil Belajar Matematika". Jurnal SAP Vol. 1 No. 1 Agustus 2016 ISSN: 2527-967X

Suari, Mirah Marlia. 2008. "Penerapan Model Pembelajaran Kooperatif dengan Metode TGT (Teams Games Tournament) untuk Meningkatkan Hasil Belajar Siswa pada Mata Pelajaran Ekonomi di Kelas X-6 Semester 1 SMAN 2 Singaraja Tahun Ajaran 2008/2009". E-Jurnal Undiksha Vol 1 No 12008.

Sudimahayasa, Nyoman. 2015. "Penerapan Model Pembelajaran TGT Untuk Meningkatkan Hasil Belajar, Partisipasi, dan Sikap Siswa". Jurnal Pendidikan dan Pengajaran, Jilid 48, Nomor 1-3, April 2015, hlm. 45-53.

Sudjana, Nana. 1987. Dasar-Dasar Proses Belajar Mengajar. Bandung: Sinar Baru Algensindo.

Toyamah, Nina dan Syaikhu Usman. 2004. Alikoasi Anggaran Pendidikan di Era Otonomi Daerah: Implikasinya terhadap Pengelolaan Pelayana Pendidikan Dasar. Tersedia pada http://www. smeru.or.id/report/field/alokasianggaranpendidikan/alokasianggaran pendidikan.pdf indeks php. Diakses pada tanggal 12 November 2011.

Wulandari, Novita. 2014. "Penerapan Pembelajaran Kooperatid Tipe Times Games Tournament (TGT) Melalui Media Permainan Ular Tangga yang dapat Meningkatkan Hasil Belajar IPA Siswa Kelas IV SDN Sumbersuko 02 Kecamatan Wagir Kabupaten Malang". Jurnal FKIP Universitas Kanjuruhan Vol 2 No 12014. 